\title{
Pedobacter caeni sp. nov., a novel species isolated from a nitrifying inoculum
}

Correspondence

Bram Vanparys

bram.vanparys@ugent.be
Bram Vanparys, Kim Heylen, Liesbeth Lebbe and Paul De Vos

Laboratory of Microbiology, Department of Biochemistry, Physiology and Microbiology, Ghent University, K.L. Ledeganckstraat 35, B-9000 Gent, Belgium
At present, the genus Pedobacter (family Sphingobacteriaceae) comprises five species: Pedobacter heparinus, Pedobacter piscium, Pedobacter africanus, Pedobacter saltans (Steyn et al., 1998) and Pedobacter cryoconitis (Margesin et al., 2003).

Amongst organisms isolated from an enriched nitrifying community, LMG $22862^{\mathrm{T}}$ was recovered on a standard mineral medium with $1.69 \mathrm{mM}$ succinate (Stanier et al., 1966) incubated aerobically at $22^{\circ} \mathrm{C}$ for 3 weeks. Briefly, an enrichment of the autotrophic nitrifying community from natural surface water was stimulated by adding a daily load of nitrogen [117.4 g TAN (total ammoniacal nitrogen) day $^{-1}$ as ammonium chloride and $58 \cdot 6 \mathrm{~g} \mathrm{NO}_{2}^{-}-\mathrm{N} \mathrm{day}^{-1}$ as sodium nitrite]. During this process, no organic carbon and only limited amounts of micronutrients were added. The purpose of the enriched nitrifying community is to enhance removal of ammonia and nitrite in aquaria and aquacultures; for more detailed information refer to Grommen et al. (2002).

The nearly complete $16 \mathrm{~S}$ rRNA gene sequence of LMG $22862^{\mathrm{T}}$ (AJ786798) was determined as described below. DNA was extracted according to Pitcher et al. (1989) as modified by Heyndrickx et al. (1996). PCR amplification was performed as described previously (Heyrman \& Swings, 2001). PCR-amplified 16S rRNA gene products were purified using the Nucleofast 96 PCR system (Millipore). For each sequence reaction a mixture of $1 \mu$ l purified product, $1 \mu \mathrm{l}$ of BigDye Termination RR mix version 3.1 (Perkin

Published online ahead of print on 14 January 2005 as DOI 10.1099/ ijs.0.63635-0.

The GenBank/EMBL/DDBJ accession number for the 16S rRNA gene sequence of LMG $22862^{\top}$ is $A J 786798$.
Elmer), $1 \cdot 5 \mu$ l BigDye buffer $(5 \times)$ and $3 \mu \mathrm{l}\left(20 \mathrm{ng}^{-1} \mathrm{l}^{-1}\right)$ of one of the six sequencing primers was used. MilliQ water was added to a total volume of $10 \mu$ l. The primers and PCR program were previously described (Heyrman \& Swings, 2001). Sequence analysis was performed using an Applied Biosystems 3100 DNA Sequencer following the protocols of the manufacturer (Perkin-Elmer). The sequence was assembled with the Kodon version 2.0 software package (Applied Maths). FASTA analysis at the EMBL database (Pearson \& Lipman, 1988) indicated that LMG $22862^{\mathrm{T}}$ was most closely related to species of the genus Pedobacter. Phylogenetic analysis using Kodon version 2.0 showed that LMG $22862^{\mathrm{T}}$ was most closely related to $P$. africanus $(98 \cdot 0 \%)$ and P. heparinus (97.6\%) (Fig. 1).

The DNA G + C content of LMG $22862^{\mathrm{T}}$, determined by HPLC (Mesbah et al., 1989) according to the further specifications given by Logan et al. (2000), was $42 \cdot 7 \mathrm{~mol} \%$. This is within the range of $36-45 \mathrm{~mol} \%$ given in the genus description (Steyn et al., 1998). DNA-DNA hybridization experiments were performed between LMG $22862^{\mathrm{T}}, P$. heparinus LMG $4024^{\mathrm{T}}$ and $P$. africanus LMG $10353^{\mathrm{T}}$ using a modification of the microplate method of Ezaki et al. (1989) as described by Willems et al. (2001). A hybridization temperature of $32{ }^{\circ} \mathrm{C}$ (calculated with correction for the presence of $50 \%$ formamide) was used. LMG $22862^{\mathrm{T}}$ showed DNA-DNA relatedness values of $12 \cdot 1 \%$ to $P$. heparinus LMG $4024^{\mathrm{T}}$ and $14 \cdot 0 \%$ to $P$. africanus LMG $10353^{\mathrm{T}}$.

A quantitative analysis of cellular fatty acid content was performed using the GLC procedure previously described (Mergaert et al., 1993), with cells grown on TSA for $48 \mathrm{~h}$ at $28^{\circ} \mathrm{C}$. The fatty acid profiles of LMG $22862^{\mathrm{T}}$, together with the profiles of the type strains of its closest phylogenetic 


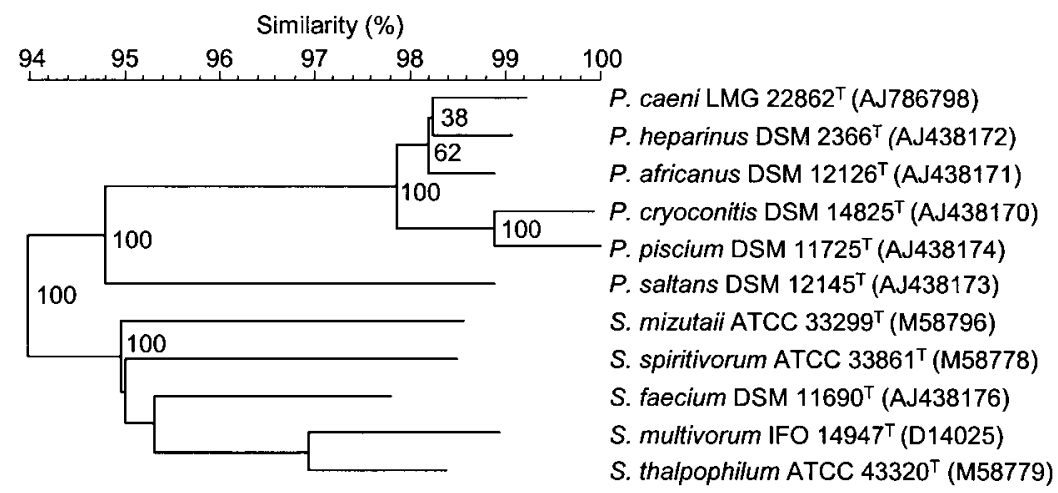

Fig. 1. Phylogenetic dendrogram obtained by neighbour-joining clustering of $16 \mathrm{~S}$ rRNA gene sequences showing the position of LMG $22862^{\top}$ among the type strains of Pedobacter and Sphingobacterium species. EMBL accession numbers are shown in parentheses. Relevant bootstrap values (expressed as percentages of 1000 replications) are shown at branch points.

neighbours $P$. heparinus and $P$. africanus, are shown in Table 1 . The dominant fatty acids were iso- $\mathrm{C}_{15: 0}$, summed feature 3 (iso- $\mathrm{C}_{15: 0} 2-\mathrm{OH} / \mathrm{C}_{16: 1} \omega 7 c$ ) and iso- $\mathrm{C}_{17: 0} 3-\mathrm{OH}$. Significant amounts of iso- $\mathrm{C}_{15: 0} 2-\mathrm{OH} / \mathrm{C}_{16: 1} \omega 7 c$ are characteristic of all representatives of the family Sphingobacteriaceae (Steyn et al., 1998). UPGMA clustering with the Canberra metric distance coefficient using BioNumerics version 3.5 (Applied Maths) showed $74 \%$ similarity of LMG $22862^{\mathrm{T}}$ to $P$. heparinus LMG $4024^{\mathrm{T}}$ and $69 \%$ to P. africanus LMG $10353^{\mathrm{T}}$.

For SDS-PAGE of whole-cell proteins, isolates were grown on phosphate-buffered nutrient agar (NA) ( $\mathrm{pH} \mathrm{6.8)}$ and incubated aerobically at $28^{\circ} \mathrm{C}$ for $48 \mathrm{~h}$. The preparation of whole-cell proteins and SDS-PAGE were performed as described by Pot et al. (1994). Densitometric analysis, normalization and interpolation of the protein profiles were performed using the GelCompar 4.2 software package (Applied Maths). UPGMA clustering of the protein profiles

Table 1. Cellular fatty acid composition expressed as percentages of the total fatty acid content

Strains: 1, P. caeni LMG $22862^{\mathrm{T}}$; 2, P. africanus LMG $10353^{\mathrm{T}}$; 3, $P$. heparinus LMG $4024^{\mathrm{T}}$. tr, Trace $(<1.0 \%)$; - , not detected; Summed feature 3 contains iso- $\mathrm{C}_{15: 0} 2-\mathrm{OH}$ and/or $\mathrm{C}_{16: 1} \omega 7 c$.

\begin{tabular}{|lccc|}
\hline Fatty acid & $\mathbf{1}$ & $\mathbf{2}$ & $\mathbf{3}$ \\
\hline $\mathrm{C}_{14: 0}$ & $2 \cdot 5$ & $1 \cdot 2$ & $1 \cdot 1$ \\
$\mathrm{C}_{15: 1} \omega 6 c$ & - & $\operatorname{tr}$ & - \\
iso- $_{15: 0}$ & $21 \cdot 3$ & $33 \cdot 3$ & $27 \cdot 9$ \\
anteiso- $\mathrm{C}_{15: 0}$ & $\operatorname{tr}$ & $1 \cdot 0$ & $\operatorname{tr}$ \\
$\mathrm{C}_{15: 0} 2-\mathrm{OH}$ & $\operatorname{tr}$ & $\operatorname{tr}$ & $\operatorname{tr}$ \\
iso- $\mathrm{C}_{15: 0} 3-\mathrm{OH}$ & $3 \cdot 3$ & $2 \cdot 1$ & $3 \cdot 6$ \\
$\mathrm{C}_{16: 0}$ & $3 \cdot 0$ & $2 \cdot 2$ & $2 \cdot 2$ \\
$\mathrm{C}_{16: 1} \omega 5 c$ & $2 \cdot 5$ & $1 \cdot 3$ & $1 \cdot 9$ \\
$\mathrm{C}_{16: 0} 3-\mathrm{OH}$ & $2 \cdot 8$ & $1 \cdot 6$ & $2 \cdot 2$ \\
iso-C $17: 1 \omega 9 c$ & $2 \cdot 2$ & $6 \cdot 5$ & $6 \cdot 4$ \\
anteiso- & $\operatorname{tr}$ & - & - \\
$\mathrm{C}_{17: 0} 2-\mathrm{OH}$ & $1 \cdot 3$ & $\operatorname{tr}$ & $2 \cdot 7$ \\
iso- $\mathrm{C}_{17: 0} 3-\mathrm{OH}$ & $12 \cdot 1$ & $16 \cdot 1$ & $14 \cdot 0$ \\
Summed feature 3 & $39 \cdot 9$ & $26 \cdot 5$ & $31 \cdot 7$ \\
\hline
\end{tabular}

(data not shown) revealed $80 \%$ similarity of LMG $22862^{\mathrm{T}}$ to the type strains of $P$. heparinus and $P$. africanus. This observation further supports the conclusion that LMG $22862^{\mathrm{T}}$ belongs to a novel species within the genus Pedobacter.

Cell morphology was investigated by light microscopy at $\times 1000$ of cells grown on TSA for $48 \mathrm{~h}$ at $28^{\circ} \mathrm{C}$. Cells were Gram stained and examined for catalase and oxidase activity. Utilization of carbon sources and enzyme production (Table 2) were tested using API $20 \mathrm{NE}$, API $50 \mathrm{CH}$ and API ZYM strips (bioMérieux) according to the manufacturer's instructions. Antimicrobial susceptibilities (Table 2) were determined with the disc diffusion method using a ST6090 Disc Dispenser (Oxoid). Antibiograms were determined according to the conventional KirbyBauer method (Bauer et al., 1966). Isolates were classified into three categories based on the quantitative interpretation criteria recommended by the NCCLS (1993).

In agreement with the genus description of Pedobacter (Steyn et al., 1998), LMG $22862^{\mathrm{T}}$ was positive for oxidase, catalase, acid and alkaline phosphatase, esterase lipase, leucine arylamidase and $\beta$-galactosidase. It hydrolyses aesculin and assimilates D-glucose, D-mannose, amygdalin and glucosamine. Indole production, urease, gelatinase, trypsin, $\alpha$-fucosidase and the ability to assimilate D-melezitose are absent. It does not give a flexirubin reaction with $20 \% \mathrm{KOH}$. In contrast to the genus description, LMG $22862^{\mathrm{T}}$ is negative for $\alpha$-glucosidase and $N$-acetyl- $\beta$-glucosaminidase.

\section{Description of Pedobacter caeni sp. nov.}

Pedobacter caeni (ca.e'ni. L. gen. neut. n. caeni of sludge).

After $48 \mathrm{~h}$ incubation at $28^{\circ} \mathrm{C}$ on TSA and NA, colonies are $0 \cdot 5-8 \mathrm{~mm}$, smooth, convex, round, slimy, initially creamy white, turning to yellow when ageing. Cells are rod-shaped $(0 \cdot 5-1 \mu \mathrm{m}$ wide and 3-10 $\mu \mathrm{m}$ long), Gram-negative, nonspore-forming. Formation of filaments is observed. No motility was observed. Cells are oxidase- and catalasepositive. Good growth is obtained after incubation for $48 \mathrm{~h}$ at $28^{\circ} \mathrm{C}$ on TSA and NA; very slow growth occurs at $37^{\circ} \mathrm{C}$. Can be differentiated from the type strains of its closest phylogenetic neighbours, $P$. heparinus LMG $4024^{\mathrm{T}}$ 
Table 2. Physiological characteristics of the type strains of $P$. caeni sp. nov., $P$. africanus and $P$. heparinus

Strains: 1, P. caeni LMG $22862^{\mathrm{T}}$; 2, P. africanus LMG $10353^{\mathrm{T}}$; 3, P. heparinus LMG $4024^{\mathrm{T}}$. +, Positive; -, negative; $(+)$, weakly positive. All strains are positive for the following features: aesculin hydrolysis, presence of catalase, oxidase, $\beta$-galactosidase, acid and alkaline phosphatase, esterase lipase, leucine arylamidase and assimilation of the following substrates: L-arabinose, D-glucose, D-mannose, methyl $\alpha$-D-mannoside, methyl $\alpha$-D-glucoside, $N$ acetylglucosamine, amygdalin, aesculin, salicin, D-cellobiose, D-lactose, D-melibiose, D-sucrose, D-trehalose, D-maltose and gentiobiose. All strains are negative for the following features: reduction of nitrate, indole production, glucose fermentation, $\alpha$-galactosidase, $\beta$-glucuronidase, arginine dihydrolase, urease, gelatinase, esterase, lipase, valine arylamidase, cystine arylamidase, trypsin, chymotrypsin, $\alpha$-fucosidase and assimilation of the following substrates: glycerol, erythritol, D-arabinose, D-ribose, methyl $\beta$ D-xyloside, L-sorbose, dulcitol, inositol, inulin, D-melezitose, glycogen, D-lyxose, D-tagatose, D-fucose, D-arabitol, L-arabitol, gluconate, 2-ketogluconate, 5-ketogluconate, caprate, adipate, malate, citrate and phenylacetate. All strains are resistant to the antibiotics gentamicin $(10 \mu \mathrm{g})$, vancomycin $(30 \mu \mathrm{g})$, methicillin $(5 \mu \mathrm{g})$, kanamycin $(30 \mu \mathrm{g})$, polymyxin $\mathrm{B}(300 \mathrm{U})$, ciprofloxacin $(5 \mu \mathrm{g})$ and ampicillin $(10 \mu \mathrm{g}) . \mathrm{R}$, Resistant; S, sensitive; I, intermediate. Data are from this study unless indicated.

\begin{tabular}{|c|c|c|c|}
\hline Characteristic & 1 & 2 & 3 \\
\hline \multicolumn{4}{|l|}{ Enzyme activities } \\
\hline Naphthol-AS-BI-phosphohydrolase & - & + & + \\
\hline$\alpha$-Glucosidase & - & + & + \\
\hline$\beta$-Glucosidase & - & + & - \\
\hline$N$-Acetyl- $\beta$-glucosaminidase & - & + & + \\
\hline$\alpha$-Mannosidase & - & - & $(+),-^{\star}$ \\
\hline \multicolumn{4}{|l|}{ Assimilation of: } \\
\hline D-Xylose & - & + & + \\
\hline L-Xylose & + & - & - \\
\hline D-Adonitol & - & - & + \\
\hline D-Galactose & - &,$-+^{*}$ & + \\
\hline D-Fructose & - & - & + \\
\hline L-Rhamnose & - & + & + \\
\hline D-Mannitol & - & - & + \\
\hline D-Sorbitol & - & - & + \\
\hline Arbutin & + & - & - \\
\hline D-Raffinose & + & - & - \\
\hline Starch & + & - & - \\
\hline Xylitol & + &,$+-^{*}$ & - \\
\hline D-Turanose & - & + & + \\
\hline L-Fucose & - & - & + \\
\hline \multicolumn{4}{|l|}{ Sensitivity to antibiotics } \\
\hline Chloramphenicol $(30 \mu \mathrm{g})$ & $\mathrm{R}$ & S & s \\
\hline Rifampicin $(5 \mu \mathrm{g})$ & S & I & I \\
\hline Amikacin $(30 \mu \mathrm{g})$ & S & $\mathrm{R}$ & $\mathrm{R}$ \\
\hline Tetracycline $(30 \mu \mathrm{g})$ & $S$ & I & $\mathrm{R}$ \\
\hline
\end{tabular}

${ }^{\star}$ Data from Steyn et al. (1998). and $P$. africanus LMG $10353^{\mathrm{T}}$, by its ability to assimilate L-xylose, arbutin, D-raffinose and starch, by its inability to assimilate D-xylose, L-rhamnose and D-turanose and by the absence of the enzymes naphthol-AS-BI-phosphohydrolase, $\alpha$-glucosidase and $N$-acetyl- $\beta$-glucosaminidase.

The type strain, LMG $22862^{\mathrm{T}}$ ( $=$ DSM $16990^{\mathrm{T}}$ ), was isolated from a commercial nitrifying inoculum in Gent, Belgium.

\section{Emended description of the genus Pedobacter}

In contrast to the genus description given by Steyn et al. (1998), this study shows that strains belonging to Pedobacter are variable for the presence of $\alpha$-glucosidase and $N$-acetyl- $\beta$-glucosaminidase.

\section{Acknowledgements}

This work was supported by project grant G.O.A. 1205073 (2003-2008) of the 'Ministerie van de Vlaamse Gemeenschap, Bestuur Wetenschappelijk Onderzoek' (Belgium) and the FWO project G20156.02.

\section{References}

Bauer, A. W., Kirby, W. M. M., Sherris, J. C. \& Turck, M. (1966). Antibiotic susceptibility testing by a standardized single disk method. Am J Clin Pathol 45, 493-496.

Ezaki, T., Hashimoto, Y. \& Yabuuchi, E. (1989). Fluorometric deoxyribonucleic acid-deoxyribonucleic acid hybridization in microdilution wells as an alternative to membrane filter hybridization in which radioisotopes are used to determine genetic relatedness among bacterial strains. Int J Syst Bacteriol 39, 224-229.

Grommen, R., Van Hauteghem, I., Van Wambeke, M. \& Verstraete, W. (2002). An improved nitrifying enrichment to remove ammonium and nitrite from freshwater aquaria systems. Aquaculture 211, $115-124$.

Heyndrickx, M., Vauterin, L., Vandamme, P., Kersters, K. \& De Vos, P. (1996). Applicability of combined amplified ribosomal DNA restriction analysis (ARDRA) patterns in bacterial phylogeny and taxonomy. J Microbiol Methods 26, 247-259.

Heyrman, J. \& Swings, J. (2001). $16 \mathrm{~S}$ rDNA sequence analysis of bacterial isolates from biodeteriorated mural paintings in the Servilia tomb (necropolis of Carmona, Seville, Spain). Syst Appl Microbiol 24, 417-422.

Logan, N. A., Lebbe, L., Hoste, B. \& 7 other authors (2000). Aerobic endospore-forming bacteria from geothermal environments in northern Victoria Land, Antarctica, and Candlemas Island, South Sandwich archipelago, with the proposal of Bacillus fumarioli sp. nov. Int J Syst Evol Microbiol 50, 1741-1753.

Margesin, R., Spröer, C., Schumann, P. \& Schinner, F. (2003). Pedobacter cryoconitis sp. nov., a facultative psychrophile from alpine glacier cryoconite. Int J Syst Evol Microbiol 53, 1291-1296.

Mergaert, J., Verdonck, L. \& Kersters, K. (1993). Transfer of Erwinia ananas (synonym, Erwinia uredovora) and Erwinia stewartii to the genus Pantoea emend. as Pantoea ananas (Serrano 1928) comb. nov. and Pantoea stewartii (Smith 1898) comb. nov. respectively, and description of Pantoea stewartii subsp. indologenes subsp. nov. Int J Syst Bacteriol 43, 162-173.

Mesbah, M., Premachandran, U. \& Whitman, W. B. (1989). Precise measurement of the $\mathrm{G}+\mathrm{C}$ content of deoxyribonucleic acid by highperformance liquid chromatography. Int J Syst Bacteriol 39, 159-167. 
NCCLS (1993). Performance standards for antimicrobial disk susceptibility tests, 5th edn. Approved standard M2-A5. Villanova, PA: National Committee for Clinical Laboratory Standards.

Pearson, W. R. \& Lipman, D. J. (1988). Improved tools for biological sequence comparison. Proc Natl Acad Sci U S A 85, 2444-2448.

Pitcher, D. G., Saunders, L. A. \& Owen, N. A. (1989). Rapid extraction of bacterial genomic DNA with guanidium thiocyanate. Lett Appl Microbiol 8, 151-156.

Pot, B., Vandamme, P. \& Kersters, K. (1994). Analysis of electrophoretic whole organism protein fingerprints. In Chemical Methods in Prokaryotic Systematics, pp. 493-521. Edited by M. Goodfellow \& A. G. O'Donnell, Chichester: Wiley.
Stanier, R. Y., Palleroni, N. J. \& Doudoroff, M. (1966). The aerobic pseudomonads: a taxonomic study. J Gen Microbiol 43, 159-271.

Steyn, P. L., Segers, P., Vancanneyt, M., Sandra, P., Kersters, K. \& Joubert, J. J. (1998). Classification of heparinolytic bacteria into a new genus, Pedobacter, comprising four species: Pedobacter heparinus comb. nov., Pedobacter piscium comb. nov., Pedobacter africanus sp. nov. and Pedobacter saltans sp. nov. Proposal of the family Sphingobacteriaceae fam. nov. Int J Syst Bacteriol 48, 165-177.

Willems, A., Doignon-Bourcier, F., Goris, J., Coopman, R., de Lajudie, P., De Vos, P. \& Gillis, M. (2001). DNA-DNA hybridization study of Bradyrhizobium strains. Int J Syst Evol Microbiol 51, $1315-1322$. 